J. Clin. Chem. Clin. Biochem.

Vol. 15, 1977, pp. 519-521

\title{
Determination of the Activity of Aminotransferases: \\ Comparison of Two Buffer Systems with and without Supplementary Pyridoxal-5' -phosphate
}

\author{
By J. C. M. Hafkenscheid and C. C. M. Dijt \\ Laboratory for Clinical Chemistry, Department of Internal Medicine, St. Radboud Hospital, \\ University of Nijmegen, Nijmegen, The Netherlands
}

(Received February 2/April 8, 1977)

Summary: A comparison was made between the aminotransferase activities of a number of plasma or serum samples in 4 reaction media: phosphate buffer, phosphate buffer + pyridoxal- $5^{\prime}$-phosphate, tris buffer and tris buffer + pyridoxal-5'-phosphate. The reactions were carried out in the various buffer systems on the same day at $35^{\circ} \mathrm{C}$ on an automatic kinetic enzyme system (AKES, Vitatron, Dieren, the Netherlands).

The highest enzymic activity of both aminotransferases is observed in tris buffer + pyridoxal-5'-phosphate. The activity is about $10-15 \%$ higher than in phosphate buffer + pyridoxal- 5 -phosphate. Without supplementary pyridoxal-5'-phosphate the differences between both buffer systems are lower or absent.

It appears necessary, therefore, to determine the activity of both aminotransferases in a buffer system with tris and to add pyridoxal- $5^{\prime}$-phosphate, since assays should be carried out in the presence of optimal concentrations of any of the necessary factors.

\section{Bestimmung der Aminotransferase-Aktivität: \\ Vergleich von zwei Puffersystemen mit und ohne Zugabe von Pyridoxal-5'-phosphat}

Zusammenfassung: Es wird ein Vergleich gezogen zwischen den Aminotransferase-Aktivitäten von einer Anzahl Plasma- und Serumproben in 4 Testansätzen: Phosphatpuffer, Phosphatpuffer + Pyridoxal-5'-phosphat, Trispuffer und Trispuffer + Pyridoxal-5'-phosphat. An ein und demselben Tag wurden die Bestimmungen durchgeführt bei $35^{\circ} \mathrm{C}$ am Automatic Kinetic Enzyme System (AKES, Vitatron, Dieren, die Niederlande).

Man findet die höchste Enzymaktivität beider Aminotransferasen in Trispuffer + Pyridoxal-5'-phosphat. Die Aktivität ist etwa 10-15\% höher als in Phosphatpuffer + Pyridoxal-5'-phosphat. Ohne den Zusatz von Pyridoxal-5'-phosphat sind die Differenzen zwischen beiden Puffersystemen geringer oder fehlen.

Es ist darum wichtig, die Aktivität beider Aminotransferasen in einem Puffersystem mit Trispuffer unter Zugabe von Pyridoxal-5'-phosphat zu bestimmen, da Enżymbestimmungen unter Zusatz von allen wichtigen Faktoren in optimaler Konzentration durchgeführt werden sollen.

\section{Introduction}

Karmen (1) in 1955 introduced the malate dehydrogenase/NADH coupled assay for the measurement of serum aspartate aminotransferase activity. Most techniques which have been introduced since then for the determination of aminotransferase activities are adaptations of NADH dependent enzyme reactions. Until recently the most commonly employed buffer system was a phosphate buffer. Die Deutsche Gesellschaft für Klinische Chemie in 1972 also recommended the use of a phosphate buffer
(2), but tris would to be better for aminotransferases, because of the increased NADH stability in this system $(3,4,5)$.

Although some recommendations $(2,5)$ do not include the use of pyridoxal-5'-phosphate in the measurement of aminotransferases it is now well established, that this coenzyme enhances the activity of these enzymes $(6,7$, $8,9)$. Also the Expert Panel on Enzymes of the Committee on Standards of the IFCC has proposed the use of tris buffer for the determinations of aspartate aminotrans- 
ferase activity (10). Pyridoxal-5'-phosphate must be added for maximal enzymic activity.

It is now important to be aware of the similarities and differences between the new recommendations and the formerly accepted methods. We have, therefore, tested the aspartate aminotransferase and alanine aminotransferase activities of a number of plasma and serum samples in phosphate and tris buffer with and without supplementary pyridoxal-5' -phosphate.

\section{Materials and Methods}

Blood was taken from patients or normal individuals by venipuncture. After centrifugation the plasma (heparinised) or serum samples were stored at $+4^{\circ} \mathrm{C}$ and assayed for aminotransferase activity within $24 \mathrm{~h}$ after the collection of the blood.

The aminotransferase activities were determined according to the following methods, in which the reaction medium containing phosphate buffer was compared with the medium containing tris buffer. All determinations were carried out in the absence or presence of pyridoxal-5'-phosphate. In this way 4 comparable sets of results were obtained.

The final reaction mixture for the aspartate aminotransferase estimation contained per liter; tris buffer $\mathrm{pH} 7.720 \mathrm{mmol}$ or phosphate buffer pH $7.780 \mathrm{mmol}, L$-aspartate $200 \mathrm{mmol}$, EDTA $5 \mathrm{mmol}$, lactate dehydrogenase (EC 1.1.1.27) $\geqslant 200 \mathrm{U}$, malate dehydrogenase (EC 1.1.1.37) $\geqslant 600 \mathrm{U}$, NADH $0.15 \mathrm{mmol}$ and 2-oxoglutarate $12 \mathrm{mmol}$. The volume fraction of sample was 0.15 . The assay mixture for the alanine aminotransferase contained per liter: tris buffer $\mathrm{pH} 7.420 \mathrm{mmol}$ or phosphate buffer pH $7.480 \mathrm{mmol}, L$-alanine $400 \mathrm{mmol}$, EDTA $5 \mathrm{mmol}$, lactate dehydrogenase $\geqslant 2000 \mathrm{U}$, NADH $0.15 \mathrm{mmol}$ and $2-0 \times 0-$ glutarate $12 \mathrm{mmol}$. The volume fraction of sample was 0.15 .

Enzyme reaction rates were measured at $35^{\circ} \mathrm{C}$ on the Automatic Kinetic Enzyme System (AKES, Vitatron, Dieren, the Netherlands), at $340 \mathrm{~nm}$ with a linearity setting of $10 \%$. To $0.1 \mathrm{ml}$ plasma or serum $0.5 \mathrm{ml}$ reaction medium was added. After preincubation the reaction was started by the addition of $0.05 \mathrm{ml}$ 2-oxoglutarate. All catalytic concentrations are expressed in $\mathrm{U} / \mathrm{l}$.

For the determinations with phosphate buffer the Boehringer optimized standard methods (Catalogue number 15751 and 15752) were used and for those with tris buffer the Merck test automation pack (Catalogue number 11369 and 11370) were used. Pyridoxal-5'-phosphate was purchased from Merck.

Statistical analysis was performed using Students'-t test for paired observations.

\section{Results and Discussion}

The reagent blank rates were determined in the 4 various reaction media by replacing the serum by water (table 1 ). The sample blank rate determined by starting the reaction by water instead of 2-oxoglutarate did not give any activity. Our blank rates agree with those of $H \phi r d e r$ et al (11), who found a lower reagent blank rate in the absence than in the presence of pyridoxal- 5 -phosphate in a reaction medium containing tris buffer. We did not correct for both blank rates in our determinations, because this is not directly possible in the Automatic Kinetic Enzyme System (AKES) and because, in our opinion, it is not generally usual in routine kinetic determinations of enzymes.
Tab. 1. Reagent blank rates of alanine and aspartate aminotransferase in 4 reaction media. Catalytic concentrations are expressed as the mean of 16 determinations. PLP $=$ pyridoxal $-5^{\prime}=$ phosphate.

\begin{tabular}{|c|c|c|}
\hline & $\begin{array}{l}\text { Alanine } \\
\text { aminotransferase } \\
(\mathrm{U} / \mathrm{l})\end{array}$ & $\begin{array}{l}\text { Aspartate } \\
\text { aminotransferase } \\
(\mathrm{U} / \mathrm{l})\end{array}$ \\
\hline $\begin{array}{l}\text { Phosphate buffer } \\
\text { Tris buffer } \\
\text { Phosphate buffer + PLP } \\
\text { Tris buffer + PLP }\end{array}$ & $\begin{array}{l}4.8 \\
3.8 \\
4.7 \\
4.8\end{array}$ & $\begin{array}{l}4.2 \\
\text { no result } \\
5.7 \\
0.9\end{array}$ \\
\hline
\end{tabular}

Tab. 2. Activity of alanine and aspartate aminotransferase in 4 reaction media. Catalytic concentrations are expressed in $U / 1$ as the mean of all values determined. PLP $=$ pyridoxal- $5^{\prime}$-phosphate.

\begin{tabular}{lcccccccc}
\hline & \multicolumn{2}{l}{$\begin{array}{l}\text { Alanine } \\
\text { aminotransferase }\end{array}$} & \multicolumn{4}{l}{$\begin{array}{l}\text { Aspartate } \\
\text { aminotransferase }\end{array}$} \\
& $\overline{\mathrm{x}}$ & $\mathrm{n}$ & $\mathrm{p}$ & $\overline{\mathrm{x}}$ & $\mathrm{n}$ & $\mathrm{p}$ \\
\hline Phosphate buffer & 37.8 & 168 & & 37.8 & 203 & \\
& & & n. s. & & & $<0.001$ \\
Tris buffer & 38.1 & 168 & & 39.9 & 203 & \\
Phosphate buffer + PLP & 41.3 & 168 & & 43.9 & 203 & \\
Tris buffer + PLP & 47.3 & 168 & & 48.5 & 203 & \\
\hline
\end{tabular}

Table 2 shows the enzymic activity of various serum or plasma samples of patients or normal individuals. Addition of pyridoxal- 5 -phosphate to the reaction media caused a higher activity of both aminotransferases. The enzymic activities determined in tris buffer with supplementary pyridoxal- $5^{\prime}$-phosphate are higher than in phosphate buffer with pyridoxal-5'-phosphate. Without supplementation with pyridoxal- 5 -phosphate a higher activity in tris buffer is only observed for the aspartate aminotransferase. For the alanine aminotransferase the activities in both buffer systems without pyridoxal-5'. phosphate are identical. The reactivation of the apoenzyme by pyridoxal- 5 '-phosphate is faster in tris buffer than in phosphate buffer for both aminotransferases.

Our results agree with those of Ebeling et al (3), who did not perform any statistical analysis, but it may be concluded from their data, that a significantly $(n=25$; $\mathrm{p}<0.05$ ) higher aspartate aminotransferase activity is observed in tris buffer than in phosphate buffer without the addition of pyridoxal-5'-phosphate. They did not observe a difference for the alanine aminotransferase. Rej \& Vanderlinde (12) demonstrated also a slightly (5\%) but significantly higher aspartate aminotransferase activity in tris buffer than in phosphate buffer. The highest enzyme activity of the aminotransferases is demonstrated when the assays are carried out in tris buffer with supplementary pyridoxal- $5^{\prime}$-phosphate. In phosphate buffer the activity is $10-15 \%$ lower than in tris buffer with added pyridoxal-5'-phosphate. $R e j$ et al. $(12,13)$ observed the same phenomenom for the aspartate 
aminotransferase activity, although they did not perform a direct comparison for both buffer systems. Our results are also in agreement with observations of Rodgerson (14). As far as we know, this difference in enzymic activity in the 2 buffer systems with supplementary pyridoxal-5'-phosphate has not yet been described for the alanine aminotransferase.

\section{References}

1. Karmen, A. (1955). J. Clin. Invest. 34, 126-131.

2. Empfehlungen der Deutschen Gesellschaft für Klinische Chemic (1972). Z. Klin. Chem. Klin. Biochem. 10, 182-192.

3. Ebeling, J., Meijers, C. A. M. \& Spijkers, J. B. F. (1969). Clin. Chim. Acta 25, 174-176.

4. Strandjord, P. E. \& Clayson, K. J. (1966). J. Lab. Clin. Med. $67,144-153$.

5. The Committee on Enzymes of the Scandinavian Society for Clinical Chemistry and Clinical Physiology (1974). Scand. J. Clin. Lab. Inv. 33, 291-306.

6. Hamfelt, A. (1966). Scand. J. Clin. Lab. Inv. 18 suppl. 92, $181-188$.

7. Ury, A. G. \& Chassy, J. R. (1973). Clin. Chem. 19, 140.

8. Cheung, T. \& Briggs, M. H. (1974). Clin. Chim. Acta 54, $127-129$.

9. Rosalki, S. B. \& Bayoumi, R. A. (1975). Clin. Chim. Acta 59, $357-360$.

10. Provisional Recommendations on IFCC methods for the measurement of catalytic concentrations of enzymes.
It appears, therefore, necessary to determine both aspartate and alanine aminotransferase activity in tris buffer and to add pyridoxal-5'-phosphate, because assays should always be carried out in the presence of optimal concentrations of any necessary factors (15).
Part. 2 IFCC method for aspartate aminotransferase (1976). Clin. Chim. Acta, 70, F19-F42; this J. 15, 39-51 (1977): Clin Chem. 23, 887-899 (1977).

11. Hфrder, M., Moore, R. E., \& Bowers Jr. G. N. (1976). Clin. Chem. 22, 1876-1.883.

12. Rej, R. \& Vanderlinde, R. E. (1975), Clin. Chem. 21, $1585-1591$.

13. Rej, R., Fasce, C. F. \& Vanderlinde, R. E. (1973). Clin. Cliem. 19, 92-98.

14. Rodgerson, D. O. (1976). In Proc. Sec. Int. Symp. Clin. Enzymology. (Tietz, N. W., Weinstock, A. \& Rodgerson, D. O., ed.), publ. by AACC, Winston-Salem, 119-134.

15. Moss, D. W. (1976). Clin. Chim. Acta 67, 169-174.

Dr. J. C. M. Hafkenschcid Laboratory for Clinical Chemistry Department of Internal Medicine St. Radboud Hospital University of Nijmegen Nijmegen The Netherlands 